\title{
Integrating Insights from Social-Ecological Interactions into Sustainable Land Use Change Scenarios for Small Islands in the Western Indian Ocean
}

\author{
Rebecca Jo Stormes Newman ${ }^{1, *}$, Claudia Capitani ${ }^{1}$ (D) Colin Courtney-Mustaphi ${ }^{2}$, \\ Jessica Paula Rose Thorn ${ }^{1,3}$, Rebecca Kariuki ${ }^{4}\left(\mathbb{D}\right.$, Charis Enns ${ }^{5}$ and Robert Marchant ${ }^{1}(\mathbb{D}$ \\ 1 York Institute for Tropical Ecosystems, Department of Environment and Geography, University of York, \\ Heslington, York, North Yorkshire YO10 5NG, UK; claudia.capitani@gmail.com (C.C.); \\ jessica.thorn@york.ac.uk (J.P.R.T.); robert.marchant@york.ac.uk (R.M.) \\ 2 Geoecology, Department of Environmental Sciences, University of Basel, Klingelbergstrasse 27, \\ 4056 Basel, Switzerland; colin.courtney-mustaphi@york.ac.uk \\ 3 African Climate and Development Initiative, University of Cape Town, Upper Campus, Geological Sciences \\ Building, Level 6, 13 Library Road, Rondebosch 7700, South Africa \\ 4 School of Life Sciences and Bio-Engineering, Nelson Mandela African Institution of Science and \\ Technology (NM-AIST), P.O. Box 447, Arusha 23306, Tanzania; rebecca.kariuki@york.ac.uk \\ 5 Geography Department, University of Sheffield, Winter St, Sheffield S3 7ND, UK; c.enns@sheffield.ac.uk \\ * Correspondence: rjsn500@york.ac.uk
}

Received: 30 December 2019; Accepted: 7 February 2020; Published: 12 February 2020

check for updates

\begin{abstract}
Small islands are vulnerable to the synergistic effects of climate change and anthropogenic disturbances due to the fact of their small area, geographical isolation, responsive ecologies, rapidly growing and developing populations and exposure to sea level and climate change. These changes exert pressures on ecosystem services, such as the provisioning of resources, and therefore threaten the sustainability of livelihoods. We reviewed key sustainability and livelihoods literature to bring together concepts of environmental livelihood resilience and stability across temporal and spatial scales and integrated them to produce a new conceptual framework for dynamic environmental livelihood sustainability (DESL). This framework aims to facilitate the incorporation of local community perspectives into water, energy and food nexus thinking about sustainable land use to support local livelihoods. Finally, we provide insights from this case study to evaluate the effectiveness of the DESL framework in addressing gaps in existing frameworks. We suggest this framing provides a mechanism for enhancing the agency of communities to produce more cohesive and inclusive land use management plans that can lead to enhanced environmental sustainability pathways.
\end{abstract}

Keywords: climate change; decision making; human well-being; nexus; participatory methods; poverty alleviation; Zanzibar

\section{Introduction}

Communities living on small islands tend to be reliant on ecosystem services for meeting their basic needs and sustaining their livelihoods [1]. However, ecosystems on small islands face unprecedented challenges due to the increasing pressures related to climate change, population increase and socioeconomic development [2]. Communities in such contexts are experiencing declines in the functioning of ecosystem services and this, in turn, threatens peoples' water, energy and food security, along with the sustainability of their livelihoods [1,3]. Following an evaluation of the capacity of existing frameworks to conceptualise and plan for environmental sustainability and livelihood sustainability, 
we suggest that existing frameworks do not adequately encapsulate how changing environmental conditions alter social-ecological behaviours in small island contexts. In response, we propose an integrative conceptual framework that captures how environmental change is altering land use on small islands with implications for environmental livelihood security. The framework we propose combines the concept of dynamic sustainability (DS) with a water, energy and food (WEF) nexus approach to help better conceptualise factors that influence environmental livelihood sustainability on small islands. We then outline how this framework can be applied through participatory scenario planning so as to ensure that future land use planning supports environmental livelihood security on small islands driven by voices from a range of stakeholders.

The article is organised as follows: in the first section, we frame our discussion by providing an overview of challenges to environmental sustainability and livelihood sustainability in small island contexts. Next, we outline existing approaches to conceptualising environmental sustainability in small island contexts. In this section, we show how the principles of sustainable livelihoods theory can be drawn into nexus approaches to deepen understanding of the environmental livelihood security of a system. However, even in doing so, there is no guarantee that local knowledge and practices will inform future policymaking and land use planning for environmental sustainability. As a result, we introduce a new integrative conceptual framework, incorporating a participatory approach that combines biophysical and social components of environmental change to evaluate the sustainability of livelihoods. This framework addresses the lack of emphasis on social-ecological relationships in existing approaches to sustainable land use planning. We suggest that the application of this conceptual framework can facilitate a greater understanding of how people interact with their environments across temporal and spatial scales to meet their basic needs in order to gain insights into how social-ecological interactions might evolve.

This framework has been developed with a focus on terrestrial landscapes on small islands and archipelagos in the Indian ocean of equatorial Eastern Africa, considering the specific water, energy and food challenges being faced on these islands. The framework is intended to guide qualitative data collection, whereby it can be combined with spatial data to inform land use planning so that the knowledge and practices of local communities are considered in these processes. In the last section of the paper, we give an example of how the framework might be applied to a stepwise scenario methodology, using Zanzibar as a case study. Using a synthesis of findings from Zanzibar, we evaluate the effectiveness of the new framework in addressing the gaps highlighted in previous examples.

\section{Background: Sustainability Challenges on Small Islands}

Environmental sustainability depends upon a balance between maintaining the capacity of ecosystems and satisfying the needs of society [4]. This definition relies upon recognition that landscapes are multifunctional; within these landscapes, social-ecological relationships are shaped by the needs of different stakeholders [5]. This approach differs from early environmental sustainability thinking which saw social and environmental systems as distinct and separate [6]. In light of these developments, various frameworks have been developed to illustrate how the social and natural components of sustainability are linked through people's behaviours [7]. We evaluated concepts from sustainable livelihoods literature, emerging dynamic sustainability principles and nexus thinking in their capacity to address sustainability challenges on small islands. Throughout this review, we drew out key principles which we felt should be combined to effectively explore the environmental sustainability of livelihoods on small islands.

\subsection{Sustainability Challenges for Small Islands}

Small islands in the Global South are being challenged by several social and environmental pressures, including population increase and rapid economic growth, leading to unplanned urban development, governance structures, sea-level rise and climate change [1,2]. On small islands, population growth, from both external and internal migration, has concentrated in coastal areas [8]. 
Tropical coastal areas are experiencing rapid economic and natural resource management changes with the rise of tourism infrastructure development $[9,10]$. Competing land uses can lead to conflicts with local communities; for instance, some hotels restrict access from the village to the beach. Seaweed farmers are also often asked not to dry the seaweed in view of hotels and in some areas coastal access has been limited using security enforcement. Seasonal tourism also increases stress on limited water resources during dry seasons [11]. Land use and land cover change has a significant bearing on the scale at which climate change impacts will be felt, by decreasing the capacity of natural capital to buffer communities against chronic and acute environmental perturbations [12]. For instance, reductions in shoreline vegetation (especially mangrove and coastal forest) mean that there are fewer natural defences against seawater intrusion, leading to soil erosion and a lower water infiltration capacity.

Coastal zones are disproportionately vulnerable to climate changes and are likely to experience a high level of multiple and interrelated climate risks with a subsequent consequence on economies [13]. As key supportive ecosystems of low-lying coastal areas and small islands continue to be removed or degraded, protection from acute natural disasters (such as storm surges and long-term changes, such as sea level rise, saline intrusion, submergence, and coastal erosion) will decline $[2,14]$. Such effects are likely to have cascading implications for water, energy and food security and thus the sustainability of livelihoods. The framework outlined by the Paris Climate Change Agreement in 2015 sets out to strengthen society's ability to adapt to the effects of climate change and build resilience at the national level. The targets set out within the Sustainable Development Goals (SDGs) also seek to support the sustainable management of ecosystems (SDG 15), end poverty (SDG 1) and increase the capacity of vulnerable people to respond to climate change effects (SDG 13). Although such policies are interconnected, pressures related to these targets have often been addressed separately, at times reducing one problem, while exacerbating another [15].

\subsection{Implications of Environmental and Socio-Economic Changes for Local Livelihoods on Small Islands}

Rural livelihood activities on small island settings often depend upon natural resource use and are underpinned by provisioning ecosystem services $[16,17]$. Coastal environments on small islands have traditionally supported deep-water fishing, bivalve collection, octopus fishing in shallow waters, aquaculture and, more recently, seaweed and sponge farming [17]. Island communities also depend highly upon coral reefs or mangrove ecosystems for coastal protection, subsistence fisheries and tourism [9]. Inland spaces have been typically used for smallholder farming, rice paddies, agroforestry and timber extraction $[16,17]$. All these activities are vulnerable to climate change. Changes in precipitation negatively impact smallholder farming livelihoods through less predictable planting times, unreliable harvests, increases in soil erosion and plant pest and disease outbreaks $[16,18]$. Whereas sea temperature rise causes coral bleaching and reef degradation with impacts on associated livelihoods (i.e., fishing, seaweed farming and reef excursions for tourism [16]). Such reductions in livelihood outcomes put rural communities at greater risk of poverty and thus the attainment of the SDGs. It must also be recognised that because of the physical characteristics of small islands, they are vulnerable to multiple stressors including both climate and non-climate related. Therefore, climate change needs to be tackled in a multi-dimensional way, addressing drivers of environmental degradation alongside climate effects [1].

Common drivers of environmental degradation include international fluctuations in market prices which influence agricultural planting decisions in terms of timing, economic returns and crop type choices [19]. As farming space is typically limited on small islands and market fluctuations are likely to have significant economic and food security effects [20]. Changes to forest legislation, such as the gazettement of protected areas, alter forest use and can shift deforestation to other areas [21]. In some cases, the expansion of tourism has caused reduced shoreline vegetation and greater exposure to the effects of sea-level rise [22]. Mangrove deforestation in particular has led to a reduction in coastal protection and other ecosystem services, particularly fish nurseries and timber [23]. Population growth increases pressure on fisheries, competition for farming land, relative food prices and firewood 
availability with the subsequent degradation of ecosystem services $[11,24,25]$. Population growth also increases requirements for wastewater treatment and can lead to pollution from nutrient loading if these needs are not met (i.e., from solid waste which is disposed of in sink pits). Introduced invasive species, such as crop pests, can have detrimental and unpredictable effects on endemic species [26]. Urbanisation and resource investments are another growing source of influence for socio-economic development on small islands. Rapid construction of tourism infrastructure, particularly in coastal spaces, has led to changes in land use and land cover and increased the demand of materials such as timber and rubble. Such demands for timber contribute to deforestation, impacting on groundwater retention and can increase the risk of groundwater salinisation due to the groundwater intrusion $[17,27]$. Tourism-related activities, such as windsurfing and snorkelling, have altered the ways in which the coastal spaces are being used, at times causing land use conflicts (i.e., between kite surfers and seaweed farmers, fishermen and snorkelling excursions, hoteliers and women collecting bivalves) [28].

Whilst these drivers leave small islands highly vulnerable, there are also some island specific opportunities to be taken into consideration. For instance, though geographically isolated, islands often have deep maritime connections that enhance their import-export capacity [29]. Strong cultural identities and social networks within small islands also enhance peoples' ability to adapt to shocks and stresses, as connectedness increases capacity for collective or shared action [8,30]. Moreover, whilst the expansion of tourism has implications for sustainable land use, there are some economic benefits to local communities in the form of formal and informal employment [31]. Higher rates of employment and development can lead to increased access to higher education of younger generations and a transition from subsistence lifestyles to income-generating activities such as working in service sectors and government offices. Road infrastructure networks also improve the connectedness between rural and urban spaces, improving mobility and market access. It is also worth noting that, despite population growth being emphasised above as a threat to environmental sustainability on small islands, there are opposing arguments for this which challenge the concept that it has adverse impacts. For instance, there are examples of innovations and technological improvements which have reduced population pressure on land and improved living conditions in Africa, even as populations have grown [32]. Considering the complexity of change, planning for future environmental sustainability on the small islands of East Africa, as elsewhere, needs to consider how drivers of change are reshaping the social-ecological relationships within those environments at different scales to better identify emerging vulnerabilities and opportunities for local livelihoods.

\subsection{Using the Sustainable Livelihoods Approach to Conceptualise Livelihood Sustainability}

For decades now, the sustainable livelihoods approach (SLA) has provided a mechanism for exploring interactions between humans and their environment and has been used to assess vulnerability, adaptability and resilience by linking to both environmental and socio-economic concerns [33]. The sustainable livelihoods framework recognises that natural resource capital contributes to rural livelihoods and that environmental stresses modify livelihood stability and augment vulnerability and opportunities for rural communities [34,35]. It was also accepted that social-ecological interactions may then change in response to environmental stresses, thereby causing further environmental degradation as people continue to meet their livelihood needs [14]. As such, the SLA touched on ecosystem service concepts, whereby the ecological system is interpreted through the lens of benefits to humans.

It has more recently been argued that links between livelihoods and ecosystems as reflected by the SLA have been overly simplified and the sustainable livelihoods framework fails to capture the complexity of socio-ecological interactions. Whilst the SLA provides valuable insights into how rural communities are connected to their environments, it only depicts these relationships in a bounded sense (direct explicit relationships) and does not account for dynamic longer-term changes such as those related to agrarian change or systematic transformations resulting from socio-political demographic, ecological succession or climatic variability and change $[33,36]$. Similarly, sustainable livelihoods theory does not sufficiently disentangle global influences on local livelihood dynamics or connect 
locally embedded contexts to wider global economic and climatic changes [37]. As such, this approach risks providing a lack of understanding about global influences on human-environmental relationships overall [36,38].

With a growing recognition of these limitations, more recent frameworks attempt to pay more attention to socio-ecological interactions across time and space including local and global level interactions that shape human and natural systems [15,39]. For example, the traditional sustainable livelihoods framework take temporality into account by exploring the effects of shocks (short-term perturbations) and stresses (longer-term changes) on the stability of livelihood outcomes [34,35]. Within the SLA, sustainability is centred on the theory of stability [40]. Others propose that stability-focused narratives on sustainability fail to acknowledge external, longer-term and less controllable dynamics (i.e., global influences and external pressures); this leaves missed opportunities when creating pathways for sustainable futures [38]. As such, principles from the SLA have been brought into adapted framings that more explicitly demonstrate the complex nature of social-ecological change resulting from the combined effects of population increase, socio-economic development and rapid environmental changes. At the same time, the water, energy and food (WEF) nexus approach has gained increasing attention within research and policy dialogue, as it has become increasingly clear that the resources that support environmental sustainability and sustainable livelihoods are inextricably linked as are their vulnerability to climate change [41,42]. Therefore, some propose that ecosystem service concepts should be embedded within nexus approaches [43]. In the section that follows, we review the capacity of different existing frameworks to address sustainability challenges on small islands and draw out key principles which we feel should be combined to address gaps.

\section{Conceptualisation: Reframing Environmental Sustainability to Better Reflect Evolving Social-Ecological Dynamics in Small Island Contexts}

At present, SLA frameworks for assessing sustainability do not adequately guide the understanding of changing social-ecological relationships and their environmental implications. We reviewed emerging frameworks for sustainability and selected defining principles from alternative existing approaches to create a new framework which could potentially facilitate a greater understanding of how local communities respond to environmental change over given temporal scales. These selected frameworks are intended to integrate theory to practice at local scales.

\subsection{Adapting the SLA to Better Represent Socio-Ecological Change}

In response to the limitations of the SLA approach, a new dynamic framing for sustainability was developed which focuses on concepts of stability, resilience, durability and robustness [38]. Within this framework, specific attention is paid to how these actions interact across temporal scales to achieve sustainability. In addition to the temporality of change, attention is also given to styles of action; specifically, whether the aim is to control or respond to shocks and stresses. This framing moves beyond traditional stability focused narratives by incorporating ideas related to resilience. Resilience thinking can provide a more proactive approach for the illumination of adaptation pathways. So far, the dynamic sustainability (DS) framework has been used within a governance and social justice context and applied to the context of managing disease epidemics [38]. However, this framing could also potentially be applied to other issue areas such as exploring how responses to change impact on the sustainability of multifunctional landscapes as well as livelihoods. We suggest that this could be achieved by evaluating the concepts of stability, resilience, durability and robustness from a social-ecological standpoint whilst incorporating land use and land cover change and resulting ecosystem function effects. This would enable better understandings of how responses to change influence environmental sustainability, allowing for predictions to be made about likely livelihood effects.

Questions could then be asked to explore how capital, financial, natural, human, physical and social assets shape the capacity of a person's or community's dynamic sustainability, thus bridging early sustainable livelihoods thinking with further advanced frameworks $[6,34,35,38]$. Learning about 
these interactions and what governs them is fundamental to understanding how drivers of change shape social-ecological relationships and thus land use and land cover patterns [44,45]. Linking together insights around changes in social-ecological relationships with the emerging consequences for ecosystem function means that resilience theory, which focuses on ecological interactions and their implications for the biosphere, can also be incorporated. Vulnerable social groups could also be identified by assessing the capacity of different groups to utilise different response strategies to achieve dynamic sustainability which will be especially useful toward addressing poverty alleviation agendas.

\subsection{Integrating Dynamic Sustainability with a Water Energy Food Nexus Approach}

Recognising that people are inextricably linked to their environment through livelihoods and thus the importance of capturing social-ecological interactions in sustainability analysis, researchers developed an integrative framework combining principles of the SLA with insights from WEF nexus thinking to assess the environmental security of livelihoods across whole systems and multiple scales [33]. Environmental livelihood security (ELS), in this sense, is defined as the ability to maintain adequate water, food and energy security to meet people's livelihood needs whilst also supporting economic growth and sustaining environmental system functionality [33]. The framework assesses interactions between a given livelihood activity and the landscape; for instance, it has been used to explore the potential impacts of climate adaptation interventions on agriculture.

Resource limitations on small islands and interactions between climate change, sustainable livelihoods and the WEF nexus are important to consider. Within small islands, local communities often undertake a diverse range of livelihood activities which draw upon water, energy and food resources [16]. Whilst the ELS framework demonstrates the capacity to cover differences in environmental conditions across spatial scales and economic sectors, there is currently a lack of interrogation about changes over retrospective and future-oriented temporal scales. Within multifunctional, landscapes, rapid socio-economic, demographic and environmental changes have implications for land use and land cover that ultimately impact on the security of water, energy and food [15,41,42]. Understanding the effects of these drivers of change requires some reflection on how they have altered the sustainability of landscapes so far [5]. Due to the rapid nature of environmental change on small islands, temporality is a particularly important aspect to consider.

Nexus approaches to conceptualising sustainability have both strengths and weaknesses. Applying a nexus approach can potentially facilitate greater communication between natural sciences and social sciences [42]. It has also been suggested that nexus-orientated workshops can provide a forum for bringing together diverse actors from different sectors to support the development of more coherent policies [15]. That said, to date, nexus studies have tended to adopt broad scale systematic approaches that fail to integrate both theoretical or applied insights [42,46]. Therefore, nexuses approaches do not fully cover the complex nature of social-ecological interactions within locally embedded contexts. Consequently, issues of power, equity and social context are often not considered in research but would be addressed within a nexus approach combined with participatory methods [6]. Therefore, thought needs to be given not only providing a framework which facilitates local knowledge exploration but also the processes by which this is undertaken.

\subsection{Towards an Integrated and Participatory Conceptualisation of Environmental Sustainability on Small Islands}

In recognition of the complex interactions between social and natural drivers of environmental change, there has been a call for more integrated approaches to exploring environmental change and enhancing resilience [41]. Responding effectively to environmental and developmental challenges involves observing the interactions of different system components at multiple scales [38]. Planned adaptation and transformative change within developing economies relies upon diverse sources which test multiple framings of adaptation and development [47]. As environmental sustainability depends upon interactions between local and global processes as well as the ecological and social characteristics 
of places and sectors, there is a need for more multidisciplinary approaches to tackle challenges [6]. New integrated approaches are needed to manage challenges created by multiple, and at times conflicting, human needs and demands to reduce poverty and promote sustainability [15]. In response to this need, recent studies have advocated for a multiscale participatory approach to development discourses $[45,48,49]$. Many researchers also discuss the importance of capturing and exploring local people's experiences and expectations when exploring climate change adaptation [50-54].

In the section that follows, we discuss a participatory and integrated framework for thinking about environmental sustainability on small islands. In small island contexts, interactions between humans and their environment are particularly strong [16]. As such, a sustainable livelihood approach which focuses on natural resource base dependence is appropriate. At present, pressures relating to population increase, climate change and socio-economic development are causing rapid environmental change on small islands [1,2]. Therefore, frameworks for exploring the sustainability of livelihoods need to incorporate temporally, so that transitions in social-ecological relationships can be identified. Our framework uses a nexus approach to better explore relationships across different sectors and identify synergies and trade-offs resulting from environmental change to inform future planning and decision making $[15,33,41]$. Furthermore, our framework adds to the growing body of work recognising that community-based experiences and insights need to be central to environmental sustainability research $[33,55]$ whilst trying to address some of the obstacles which prevent effective integration of local knowledge. As we will demonstrate in the section that follows, a nexus approach, informed by the principles of the SLA as well as local communities' knowledge, provides compelling insights into environmental sustainability issues on small islands where reliance on ecosystem services for livelihoods is high, natural resources are limited and land use demands are competitive. Importantly, this proposed conceptual framework does more than link drivers of environmental change; it informs action towards achieving environmental sustainability and involves communities in the processes shaping such action.

\subsection{Integrating Principles from Existing Frames of Thinking}

Considering insights from the above approaches, we analysed existing frameworks which address different aspects of sustainability, to combine elements from WEF and DS approaches. We also integrated concepts from participatory processes for sustainable land use planning to facilitate the generation of tangible spatial outputs. These frameworks include: the DS approach [38]; the ELS framing [33] (both theoretical frameworks) and the kesho (meaning "tomorrow" in Swahili) scenarios framework (a methodological framework) [12,45] (see Table 1). Linking theoretical concepts with a methodological framing allows us to develop a focused framework to guide researchers in data collection. The dynamic sustainability theory was selected as it allows us to explore responses to change in a way that reaches beyond traditional stability focused approaches. By incorporating aspects of resilience, we can capture grassroots innovations to change which are often not captured by existing frameworks. The ESL framework conceptualises using a water, energy, food and livelihoods nexus. Integrating livelihoods considerations into sustainability assessments is vital for small islands where communities rely heavily on ecosystem services to meet their basic needs [33]. The kesho framework offers a practical stepwise approach for integrating community insights into land use management scenarios, highlighting societal drivers in socio-ecological cause-effects interactions [12,45]. 
Table 1. Description of key existing frameworks for sustainability, their previous applications and identified gaps in terms of their capacity to integrate livelihood impacts and sustainable land use planning.

\begin{tabular}{|c|c|c|c|}
\hline Framework & Description & Application Examples & Gaps in Existing Framework \\
\hline $\begin{array}{c}\text { Dynamic } \\
\text { Sustainability [38] }\end{array}$ & $\begin{array}{l}\text { The concept of dynamic } \\
\text { sustainability was developed } \\
\text { to support a pathways } \\
\text { approach to managing } \\
\text { sustainability challenges in a } \\
\text { changing world. It is inclusive } \\
\text { of dynamics, complexity, } \\
\text { uncertainty and differing } \\
\text { narratives by considering how } \\
\text { aspects of stability, resilience, } \\
\text { durability and robustness } \\
\text { operate across temporal scales. }\end{array}$ & $\begin{array}{l}\text { The dynamic sustainability } \\
\text { framework has been used to } \\
\text { conceptualise governance } \\
\text { challenges associated with } \\
\text { disease epidemics including } \\
\text { using the examples of } \\
\text { haemorrhagic fevers and avian } \\
\text { influenza. The application } \\
\text { aimed to develop } \\
\text { sustainability pathways } \\
\text { towards managing epidemics } \\
\text { that moved beyond stability } \\
\text { focused narratives by } \\
\text { incorporating more nuanced } \\
\text { aspects of resilience theory } \\
\text { [38]. }\end{array}$ & $\begin{array}{l}\text { The framing enables } \\
\text { researchers to evaluate } \\
\text { sustainability in a changing } \\
\text { world using concepts of both } \\
\text { resilience and stability. } \\
\text { Applications have so far not } \\
\text { made tangible links with } \\
\text { ecosystem service flows across } \\
\text { spatial scales. Whilst applied } \\
\text { in a theoretical sense to explore } \\
\text { resilience focused pathways, it } \\
\text { has not been linked with } \\
\text { quantitative data to explore } \\
\text { the implications of proposed } \\
\text { trajectories of change. }\end{array}$ \\
\hline $\begin{array}{c}\text { Environmental } \\
\text { Livelihood Security (ELS) } \\
\text { [33] }\end{array}$ & $\begin{array}{l}\text { The ELS framework integrates } \\
\text { sustainable livelihoods theory } \\
\text { with water, energy and food } \\
\text { nexus approaches. The } \\
\text { approach was developed in } \\
\text { response to a lack of } \\
\text { consideration for livelihoods } \\
\text { in nexus thinking. It aims to } \\
\text { conceptualise the balance } \\
\text { between human water energy } \\
\text { and food needs with } \\
\text { environmental sustainability. }\end{array}$ & $\begin{array}{l}\text { The ESL framework has been } \\
\text { used to investigate the } \\
\text { environmental security of } \\
\text { livelihoods in Southeast Asia } \\
\text { and Oceania by assessing } \\
\text { water, energy, food and } \\
\text { livelihood interactions spatial } \\
\text { using geospatial assessments. } \\
\text { The framework was used } \\
\text { specifically to explore the } \\
\text { balance between natural } \\
\text { supply and human demand } \\
\text { for water, energy and food } \\
\text { resources [56]. }\end{array}$ & $\begin{array}{l}\text { The ELS framework links } \\
\text { social and ecological systems } \\
\text { and considers the } \\
\text { sustainability of these } \\
\text { interactions on livelihoods } \\
\text { using a water, energy, food } \\
\text { nexus lens. Whilst spatial } \\
\text { considerations are made, there } \\
\text { is a lack of temporal } \\
\text { consideration and therefore } \\
\text { the evaluations are based more } \\
\text { on stability than resilience } \\
\text { over time. Moreover, though } \\
\text { societal demand for water, } \\
\text { energy and food resources } \\
\text { plays a central role in nexus } \\
\text { considerations, the } \\
\text { mechanisms for community } \\
\text { insights to be heard is not } \\
\text { explicit. }\end{array}$ \\
\hline $\begin{array}{c}\text { Kesho (meaning } \\
\text { "tomorrow" in Swahili) } \\
{[12,45]}\end{array}$ & $\begin{array}{l}\text { Kesho is a participatory } \\
\text { framework which was } \\
\text { developed to support } \\
\text { multi-stakeholder engagement } \\
\text { in a land use and land cover } \\
\text { framework. It consists of four } \\
\text { main steps that involve experts } \\
\text { (facilitators) and stakeholders } \\
\text { (those who are affected by or } \\
\text { can affect socio-economic and } \\
\text { land dynamics): 1) scenarios } \\
\text { setting; } 2 \text { ) stakeholder-driven } \\
\text { scenario development; } 3 \text { ) } \\
\text { modelling; } 4 \text { ) synthesis, } \\
\text { feedback and consensus } \\
\text { building. }\end{array}$ & $\begin{array}{l}\text { The kesho scenarios } \\
\text { framework has been applied } \\
\text { to several East African } \\
\text { landscapes. It has been used at } \\
\text { the national level in Tanzania } \\
\text { to explore projected land cover } \\
\text { change under climate change } \\
\text { mitigation scenarios business } \\
\text { as usual and green economy } \\
\text { alternatives [45]. It has also } \\
\text { been used to assess the } \\
\text { impacts of climate change } \\
\text { adaptation in farming } \\
\text { communities in the Taita Hills, } \\
\text { Kenya and Jimma rural area in } \\
\text { Ethiopia [12]. Other } \\
\text { applications in pastoral } \\
\text { systems in the Serengeti and } \\
\text { development corridors in } \\
\text { Tanzania are ongoing. }\end{array}$ & $\begin{array}{l}\text { The kesho framework aims to } \\
\text { apply insights into } \\
\text { environmental change into } \\
\text { land use and land cover } \\
\text { models through engaging with } \\
\text { diverse stakeholders. } \\
\text { However, there are issues in } \\
\text { terms of power dynamics in } \\
\text { multi-stakeholder processes } \\
\text { that need to be considered. } \\
\text { Evaluative steps to assess the } \\
\text { impacts of alternative } \\
\text { scenarios on livelihoods could } \\
\text { also be added to link scenarios } \\
\text { outputs with poverty } \\
\text { alleviation agendas. }\end{array}$ \\
\hline
\end{tabular}

\subsection{New Integrative Framework for Exploring the Dynamic Environmental Sustainability of Livelihoods} (DESL) on Small Islands

Combining insights from the above approaches, we introduce a conceptual framework that facilitates the integration of community insights into sustainable land use scenarios by drawing together principles from social-ecological theory and sustainability to help address previous gaps. 
We suggest that this framework will help to ensure that local insights are rooted in environmental sustainability analysis. The central theme of the framework is "environmental sustainability of livelihoods" on small islands-a water, energy and food nexus is used as the lens for evaluating these livelihood outcomes (see Figure 1). The framework aims to explore how environmental drivers of change (for instance climate change, population increase and socioeconomic development) shape land use and land cover and the associated effects of this on ecosystem functions which support water, energy and food security. The framework adopts the theory of DS and applies it to the ELS concept which links ecosystem service flows relating to water, energy and food with livelihood outcomes [33,38]. In doing so, this new framework enables us to explore the dynamic sustainability of water, energy and food security under changing conditions. By incorporating a scenario approach, this framework addresses the inherent uncertainty around long-term socio-ecological dynamics and enables us to explore and anticipate such dynamics. Using the water, energy and food security lens, the components of sustainability, as outlined by in the DS framework, are redefined as:

1. Stability—the security of water, energy and food resources according to availability, access and quality;

2. Resilience-how response strategies are used to manage perturbations which affect the security of these resources;

3. Robustness-the extent to which shocks or stresses can be controlled either by grassroots responses or institutional intervention;

4. Durability—openness of society to endure change, considering the diversity of circumstances across spatial scales.

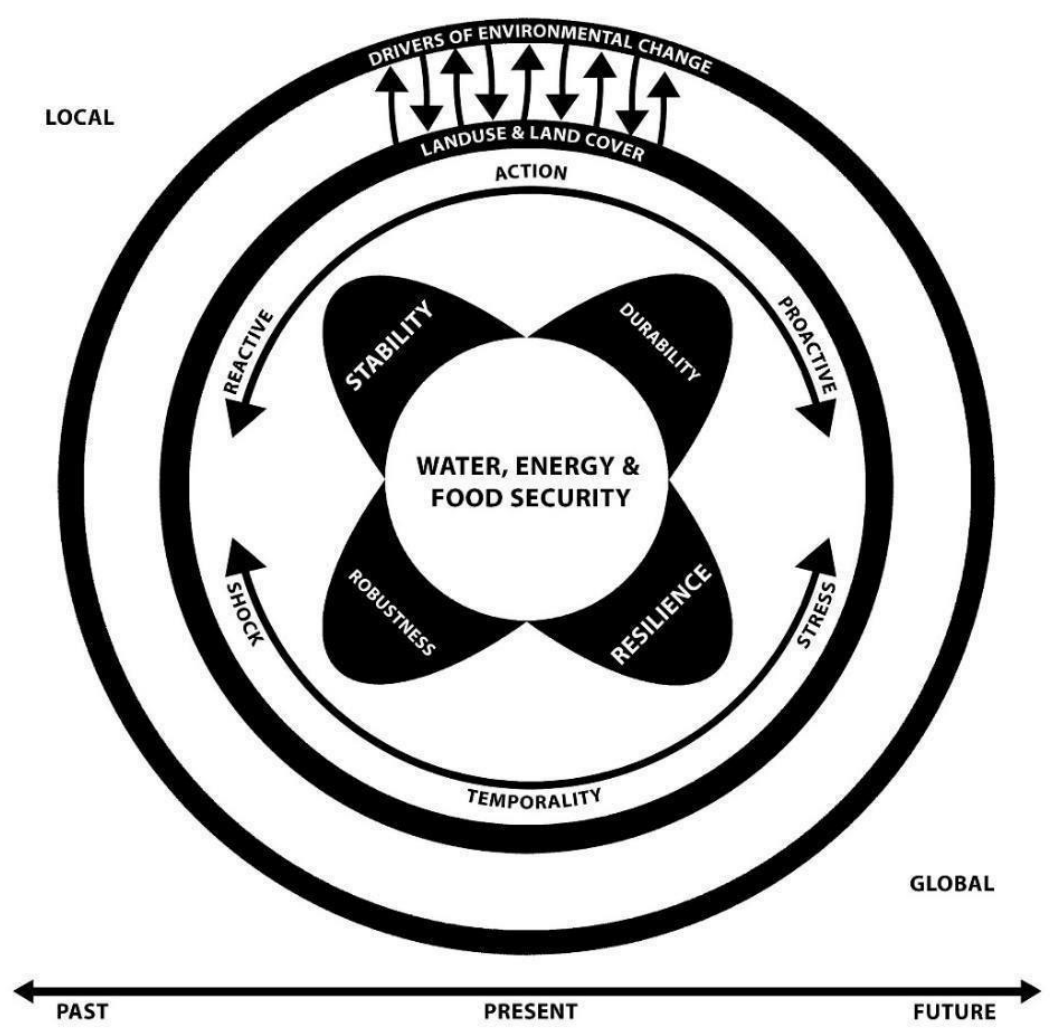

Figure 1. Dynamic environmental sustainability of livelihoods (DESL) framework for exploring how environmental drivers of change shape land use and how people's responses to such change shape the environmental sustainability of local livelihoods on small islands, drawing upon concepts from dynamic sustainability, environmental livelihood security and kesho frameworks [12,33,38]. 
The framework incorporates a temporal scale (i.e., past, present, future) for analysing response strategies; by including a temporal dimension, the evolving nature of social-ecological relationships and longer-term changes can be better understood. To assess the sustainability of people's responses, the framework aims to identify whether such responses are reactive or proactive. When reacting to a stress or shock ex-post (after an environmental change), there can be an interval of increased vulnerability which pushes communities to exploit environments to try and meet their basic needs [14]. For example, drought can result in harvest failure; coastal communities may then intensify fishing activities to meet food security needs. Alternatively, proactive interventions might be undertaken, this could increase preparedness and decrease vulnerability. With foresight, a farmer may choose to invest in an irrigation system to overcome seasonal reductions in rainfall. These styles of action (i.e., responsive and proactive) are positioned in the framework to show their relation to temporal aspects (i.e., short-term shocks and long-term changes). In this framing, long-term stresses are shown to depend on durability and resilience and lean towards proactive response strategies, whereas shocks rely on robustness within both systems and livelihoods and tend to result in responsive action to try and maintain stability. The framework ultimately tries to explore how these styles of action impact on the security of water, energy and food.

The framework also aims to capture some tangible physical changes in land use and land cover and link them with both drivers and implications of change in relation to water, energy and food security; this is especially important when trying to link to scenarios' development outputs. Drivers of change should be identified by local communities and can be both local and global; they might include changes in governance, institutions, political, social and economic factors as well as environmental factors such as climate change. Including the spatial change aspect is important for visualising future scenarios, as it gives a tangible quantitative outcome that people can use to evaluate potential water, energy and food security impacts. The explicit connection between drivers of land use change, spatial implications and livelihood outcomes is something that is missing from many other frameworks. This framework intends to facilitate the identification of drivers of land use and land cover change, assess the responses to such change and evaluate the overall implications for water, energy and food security. In the case of future scenarios development, it could be used to explore how perceived drivers of environmental change are likely to affect land use and land cover in the future and to predict the resource security impacts, with consideration to past changes. In both cases, local knowledge is fundamental to our understanding of the complex social-ecological processes that shape resource use and ultimately livelihood security.

This type of framing is particularly relevant for small island contexts, where limited space and increasing resource demands (often meaning a reliance on imports for food and fuel) result in greater levels of resource scarcity and, therefore, a greater need for land management planning [30]. Using a WEF nexus allows for better identification of trade-offs and synergies associated with different response strategies; these insights could help to identify emerging vulnerabilities and opportunities. Grassroots strategies for reducing ecosystem degradation from both land use change and climate change are especially important given that small island communities are highly dependent on ecosystem services to meet their water energy and food needs [16]. By linking response strategies with land use and land cover, we are able to better identify the outcomes on such strong interactions. Communities living on small islands are particularly likely to experience increased vulnerability as multiple drivers of change operate across small areas [1,57]. (For instance, population increase resulting in mangrove deforestation in tangent with sea-level rise, or settlement expansion resulting in less agricultural land alongside reductions in harvest due to the fact of climate change). As levels of poverty on small islands in the West Indian Ocean remain high and existing research points to increased levels of vulnerability to future environmental change (such as sea level rise and natural disasters) [30], there is a pressing need to explore the sustainability of response strategies in these strongly affected social-ecological systems. For this to occur, we suggest that there needs to be a more in-depth understanding of how 
people attempt to meet their basic needs under changing conditions and that this should involve exploring perceptions of change alongside response strategies.

\section{Application: A Case Study of Zanzibar}

In this section, we introduce a summary of a practical application for how the DESL framework was applied in Zanzibar (the islands of Unguja and Pemba) and evaluate its effectiveness based on early reflections of research outputs.

\subsection{Application of DESL Framework to the Stepwise Scenarios Process in Zanzibar}

In this section, we suggest how the conceptual framework might be applied to the scenario's development process using an example from Zanzibar (Unguja and Pemba) (see Table 2). The focus in this integrative framework centres on the environmental sustainability of local livelihoods. We emphasise the need for scoping work to be undertaken to get an insight into the social and cultural context, to better understand how people utilise environmental resources to meet basic needs and to identify shocks and stresses that impact upon on resource security (see Figure 2). This layer of contextual research helps researchers to be aware of what people feel are the main issues and will ensure that power dynamics are recognised and workshop planning can be sensitive to these. Scoping research is vital to projects which rely upon a high degree of interaction and communication with communities, as it helps to facilitate mutual respect, trust and an understanding of different viewpoints [58,59]. In Zanzibar, focus groups were undertaken in Pemba and Unguja islands with village leaders and elders across diverse land use types (peri-urban, coastal, farming, coastal forest and mature forest). This was done to gain an understanding of how people utilise ecosystem services to meet water, energy and food needs, identify perceived changes in the security of these resources and assess how people respond to such changes. Focus groups also provided an opportunity to learn about familial roles in managing household water, energy and food needs. These discussions helped to generate a greater understanding of the dynamic sustainability of water, energy and food security over time which is at the core of the DESL framework.

Table 2. Pathways approach for supporting the integration of local knowledge into problem framing and scenarios development which supports sustainable land use and land cover management for effective water, energy and food security. This involves a three-step research approach (i.e., scoping, community-based workshops and multi-stakeholder scenarios workshops).

\begin{tabular}{|c|c|c|}
\hline Research Steps & Aims & $\begin{array}{c}\text { Practical Application to Zanzibar Case } \\
\text { Study }\end{array}$ \\
\hline Focus Groups & $\begin{array}{l}\text { (1) Obtain an appreciation of the social } \\
\text { and cultural context. } \\
\text { (2) Develop an understanding of how } \\
\text { communities interact with the } \\
\text { environment to meet their water, energy } \\
\text { and food needs. } \\
\text { (3) Learn about perceived shocks and } \\
\text { stresses and their effects on water, energy } \\
\text { and food security, }\end{array}$ & $\begin{array}{l}\text { Ten focus groups were undertaken with } \\
\text { village leaders and elders (both males and } \\
\text { females) in ten villages across Unguja and } \\
\text { Pemba with a total of } 36 \text { participants. } \\
\text { Sites represented diverse land cover types } \\
\text { (peri-urban, coastal forest, mature forest, } \\
\text { farming and coastal). Focus groups used } \\
\text { semi-structured interviews and were } \\
\text { carried out in Swahili with the support of } \\
\text { a translator. Each interview was recorded } \\
\text { with a dictaphone and lasted around two } \\
\text { hours. }\end{array}$ \\
\hline
\end{tabular}


Table 2. Cont.

\begin{tabular}{|c|c|c|}
\hline Research Steps & Aims & $\begin{array}{l}\text { Practical Application to Zanzibar Case } \\
\text { Study }\end{array}$ \\
\hline Community Workshops & $\begin{array}{l}\text { (1) Explore how land use and land cover } \\
\text { has changed over time, the reasons for } \\
\text { such change and the implications for } \\
\text { water, energy and food security. } \\
\text { (2) Make predictions about key drivers of } \\
\text { change which are likely to shape land use } \\
\text { and land cover in the future. } \\
\text { (3) Create pathway themes based on } \\
\text { grassroots land use management } \\
\text { suggestions. }\end{array}$ & $\begin{array}{l}\text { Community-based workshops were } \\
\text { undertaken across the same ten sites. } \\
\text { Focus group size ranged from twelve to } \\
\text { seventeen participants, where gender was } \\
\text { balanced and represented a range of age } \\
\text { groups, from youth to the elderly. In the } \\
\text { workshops, participants produced land } \\
\text { use and land cover maps from twenty } \\
\text { years ago to today. They identified } \\
\text { changes and drivers of changes and } \\
\text { evaluated impacts on WEF security. They } \\
\text { then made predictions about future } \\
\text { changes and communicated ideas for } \\
\text { solutions to emerging challenges. } \\
\text { Workshops were } 1 \text { day each and } \\
\text { conducted in Swahili with the support of } \\
\text { a translator. }\end{array}$ \\
\hline $\begin{array}{l}\text { Multi-Stakeholder Scenarios } \\
\text { Workshops }\end{array}$ & $\begin{array}{l}\text { (1) Create timelines of land use and land } \\
\text { cover change and explore interactions } \\
\text { with the prioritised drivers highlighted in } \\
\text { community-based workshops and water, } \\
\text { energy and food security. } \\
\text { (2) Develop in-depth pathway narratives } \\
\text { to inform future scenario alternatives } \\
\text { based on themes outlined in community } \\
\text { workshops. } \\
\text { (3) Predict land use and land cover } \\
\text { scenarios under the different pathway } \\
\text { options and evaluate potential water, } \\
\text { energy and food impacts. }\end{array}$ & $\begin{array}{l}\text { Two one-day scenarios workshops were } \\
\text { undertaken, one in Pemba (44 } \\
\text { participants) and one in Unguja (23 } \\
\text { participants). Stakeholders involved } \\
\text { community representatives from all ten } \\
\text { previous sites along with members from } \\
\text { the following government sectors: } \\
\text { agriculture, forestry, environment, water, } \\
\text { energy and tourism. Two NGO bodies } \\
\text { also contributed; these included: Milele } \\
\text { foundation and Wildlife Conservation } \\
\text { Society. In these workshops, participants } \\
\text { created timelines of land use and land } \\
\text { cover change and evaluated impacts on } \\
\text { WEF security. They then developed } \\
\text { pathway narratives for supporting } \\
\text { sustainable land use scenarios based on } \\
\text { themes created by communities in earlier } \\
\text { workshops. They predicted likely land } \\
\text { use and land cover changes given each } \\
\text { pathway alternative and finally reflected } \\
\text { on the capacity of each framework to meet } \\
\text { WEF needs. Workshops were conducted } \\
\text { in Swahili again with the support of a } \\
\text { translator. }\end{array}$ \\
\hline
\end{tabular}

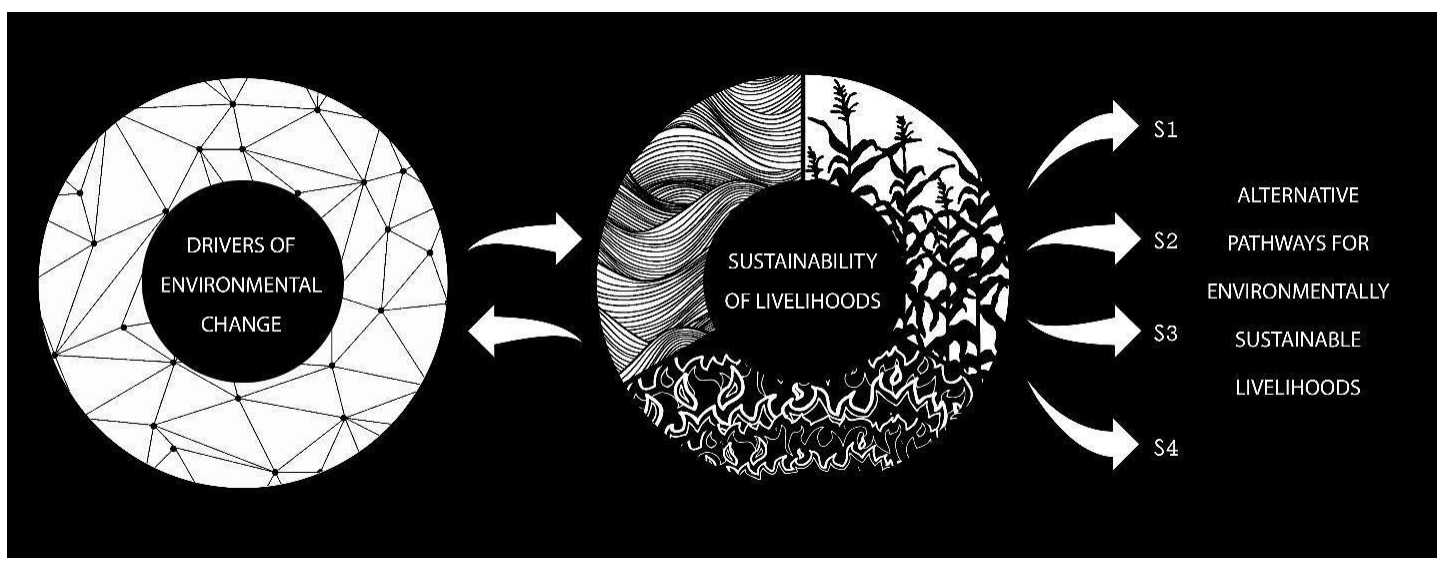

Figure 2. Schematic diagram representing the scenarios process using a water, energy and food nexus approach to explore the sustainability of livelihoods given identified drivers of environmental change. 
Once the scoping work was completed, we carried out local community-based workshops for problem framing and pathway theme development using the conceptual framework (see Figure 1) as a guide for the question set and workshop activities. Workshop activities were centred around the participatory mapping of village areas twenty years previous to the present day, identification of changes in land use and land cover over these timescales and evaluation of the impacts of change on water, energy and food security. Attention was paid to social hierarchies and dynamics within local community settings (including social structures such as village leaders and elders, patriarchal roles and expectations, the role that age plays, religious standings and education status), and fieldwork facilitators encouraged equal participation. Including communities in the problem framing is an important step in ensuring that the goals and values of key actors are demonstrated in the narrative [60]. In this case, instead of stakeholders across all levels (institutional and community) investigating the socio-economic and environmental trajectories of alternate alternative futures (as kesho was originally intended) the problem-framing and scenario pathway boundaries were developed by local communities alone. This helped to address power dynamics related to social hierarchies and imbalances in education levels [61]. It also increased the agency of local communities in decision making around alternative futures, ensuring that their perceptions about environmental change and its implications for water, energy and food security are embedded within the development of future scenarios.

The final scenarios development stage consisted of multi-stakeholder workshops which invited experts in water, energy and food sectors, professionals involved in land planning and ecosystem management and representatives from the local community-led workshops. In this workshop, groups engaged in discussions about drivers and the implications of change identified by the local communities and developed scenarios narratives based on the proposed options developed earlier by local communities. They then moved on to predict the potential spatial implications of the alternative scenarios by exploring likely land use and land cover changes across spatial scales. This provided a mechanism for participants to translate their scenarios narratives into quantitative outputs [12]. Once such predictions were made, participants worked together to evaluate the likely impact each scenario might have on water, energy and food security. In doing so, groups worked towards assessing how each scenario manages to support sustainable management of ecosystems (SDG 15), alleviation of poverty (SDG 1) and increased capacity of vulnerable people to respond to climate change impacts (SDG 13). This stage of research allowed us to refine the spatial scales at which alternative drivers of change operate in Pemba and Unguja and to generate quantitative results about predicted scales of land use change across diverse land cover types, which could be used in scenarios modelling processes. The participatory approach, combined with the nexus concept, supported social learning between both communities and professionals as well as among institutions, which ordinarily work in isolation.

\subsection{Early Reflections from the Zanzibar Application of the DESL Framework}

Early insights from empirical data collection in Zanzibar (Unguja and Pemba) using the stepwise process (see Table 2) show that there are increased pressures on ecosystem needs stemming from population increase, climate change and socio-economic development (especially in relation to tourism) (see Figure 3); this is indicative of many small islands [1,2,7,8]. Deforestation of mature and mangrove forests was a major concern in Pemba and Unguja; settlement expansion was another major land use and land cover change, resulting in deforestation (for both space and timber resources) and reduced area for agriculture. The increase in tourism on Unguja island had also caused shifts in the settlement location. Reductions in agricultural land meant subsistence plots were reduced in size and continuous farming on the same plots was thought to have reduced soil fertility. It has previously been found that farmers in Zanzibar reduced their fallow periods to try and produce more crops [16]. Crop rotation (specifically using legumes) is important for improving soil fertility; therefore, such a response could be considered maladaptive [62]. Reductions in rainfall and extended periods of drought also led to reductions and failures in crop harvest. 


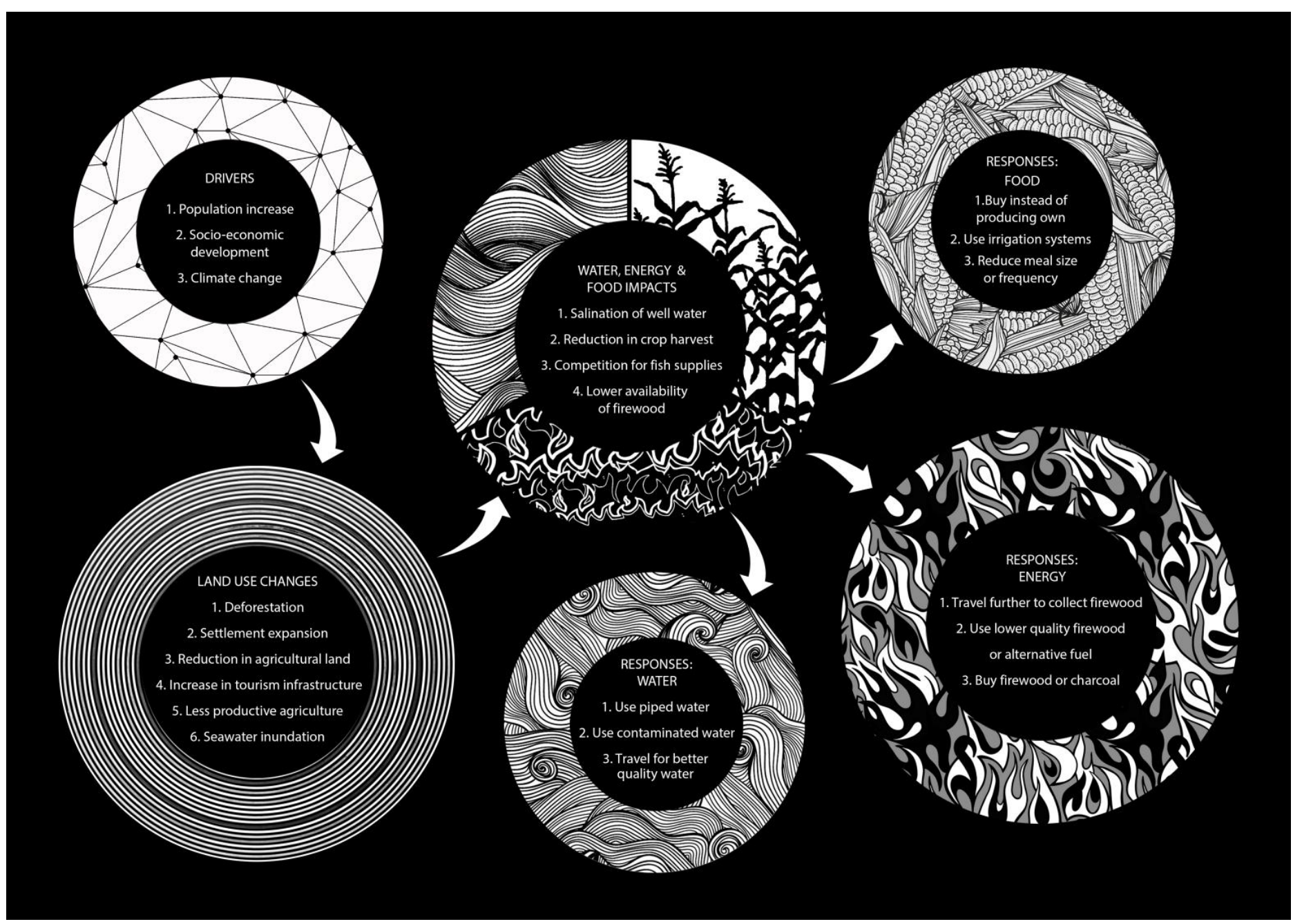

Figure 3. DESL framework outputs for the case study of Zanzibar (islands Unguja and Pemba), highlighting drivers of change, land use changes, implications for water, energy and food security and the responses utilised to try and achieve resource security. 
There were several implications for water, energy and food security as a result of land use and land cover changes. Removal of mangroves coupled with wave over-wash caused groundwater salinization; this contaminated well water and soils in agricultural plots. Salinization is experienced in many coastal villages across Pemba and Unguja. The supply of piped water was not equally distributed across villages meaning there were inequalities relating to water security, although only occasionally there have been some major disruptions in supply (for instance when Zanzibar experience a prolonged power cut in 2008). During such disruptions, communities accessing piped water had to revert to using well water. In some cases, the well water quality had not been maintained and this led to dysentery. Water quality was also thought to be compromised by inadequate wastewater treatment from hoteliers [63]. That said, most communities felt that water security had increased over the last twenty years with the introduction of piped water.

Reductions in productivity and space for agriculture often meant that households could no longer meet their food security needs through subsistence farming and had to supplement this with bought food items, making households more exposed to market fluctuations [20]. Responses to lower harvests also included reducing meal size, meal frequency or swapping protein sources, such as meat and fish, for carbohydrates like maize and rice. Food security on small islands typically depends on the ability of households to purchase imported food [64]. Small island communities' low productive potential and reliance on food imports makes them vulnerable to food insecurity arising from shocks and stresses (i.e., reduction in the production of crops due to the fact of extreme weather events, exposure to spikes in food prices or a fall in wages) [65]. Overall, communities felt that there had been a slight reduction in food security in the last twenty years with most stating that security was high in previous years and adequate at present day.

Depletion of firewood sources caused people to either travel further to find quality firewood (sometimes into other village community forest utilisation areas), use lower quality firewood, use alternative fuel sources (e.g., coconut palm, sawdust, coconut shells) or buy firewood or charcoal. Very few people used gas as an alternative fuel source due to the cost. Land shortages and rapid exhaustion of natural resources left many communities living on small islands vulnerable to energy insecurity [66]. Considering this long-standing recognition, failure to secure clean energy could be seen as a policy failure [67]. The reduction in firewood security mainly impacted on women, whose role it was to collect firewood, as they had to spend more time collecting. Communities across all study sites agreed that energy security, with regards to firewood, had substantially decreased in the last twenty years. That said, there is a clear need for energy transitions to take place, considering the health implications of combustion fuels (i.e., firewood and charcoal) such as respiratory inflammation (ARI), otitis media, chronic obstructive pulmonary disease (COPD), lung cancer, asthma, cardiovascular disease, tuberculosis, and increased blood pressure as well as heightened risk of preeclampsia in pregnant women [67].

Overall, the strategies used to cope with change and achieve a stable supply of resources were chaotic. Perturbations were often managed ex-post, meaning that people felt a reduction in resource security before implementing a coping strategy, thereby increasing vulnerability [14]. However, the resilience of individuals and households was enhanced by the robust community connectedness between family members and neighbours. Strong social networks and connectedness increased household's durability (ability to endure change). Island communities in particular demonstrate a high degree of resilience through social networks which support collective action, norms of reciprocity and relations of trust [30]. That said, it was felt that this connectedness had weakened over time with resource scarcity, meaning people sometimes adopted a more individualistic attitude when managing perturbations.

There were significant barriers which limited people's robustness for coping with environmental change (i.e., grassroots innovations). Poverty reduced people's capacity to invest in irrigation technologies and other farming inputs such as fertiliser. It also restricted people's ability to shift to other types of fuel such as gas. Lack of education about managing environmental change was highlighted 
as a major barrier to adaptation. The enhanced provisioning of clean water meant that shocks and stresses associated with groundwater salinization were largely buffered, but the inadequate stability of supply meant that communities were sometimes reverting back to poorer quality resources [63]. The general shift from subsistence to income-generating livelihoods provided some protection from harvest failures, as people's capacity to access imported foods increased. However, this has altered the movement of people; in Pemba, many communities stated that younger generations of men moved to Unguja to try and find work; whereas in Unguja, young men relocated to Stonetown (urban district) or coastal areas in search of work. Internal migration has altered social structures within communities and, as a result, reduced social cohesion. Employment opportunities were unstable and people often had to defer livelihood activities (i.e., fishing, farming, construction) to try and secure an adequate income. Opportunities in the tourism sector were generally low due to the lack of language and admin skills; those that worked in tourism generally secured gardening and housekeeping roles. Coastal communities in Zanzibar are often excluded from tourism sector employment because of poor education [28].

The participatory future scenario narratives generated centred on three defined pathways: urban and settlement planning; ecosystem protection and management; education for enhancing capacity for adaptation. Spatial planning concerned guidelines for how villages were spatially organised and indicated areas where building should be avoided such as cemeteries (due to the native trees and spiritual importance). Ecosystem protection and management concerned mature forest and mangrove forest areas and underlined the importance of community involvement in decision making and monitoring. Inadequate governance of resources is seen as a major barrier to adaptation [16]. Education needs highlighted focused especially on improving farming methods to overcome climate-related challenges and productivity issues relating to soil fertility. Low educational attainment and lack of farming knowledge are significant barriers to adaptation in Zanzibar [16]. There was an eagerness from communities themselves to become more skilled in forest management and regeneration. Under all three pathway alternatives, participants thought that water and food security would increase but that firewood security would decrease due to the mounting pressures. However, there was some confidence that the provisioning of alternative energy types would improve, and this would buffer the effects of firewood insecurity.

\section{Discussion: Evaluation of the DESL Framework Application Based on Early Reflections of the Case Study Application}

Despite recent efforts to incorporate both social and environmental systems into conceptualisations of environmental sustainability, existing frameworks do not always adequately reflect local understandings of environmental sustainability and local knowledge about environmental change. There is some progress in rural adaptation but it is insufficient for the challenges that lie ahead for coastal communities. Essentially, social systems have been brought into conceptual discussions about environmental sustainability in ways that overlook the knowledge of those most impacted by climate change. Greater emphasis is needed to understand and put in place context specific sustainable land use plans that respond to the needs of those communities at the forefront of future adaptive challenges. This is problematic, as in addition, frequently acting as custodians of ecosystems, local communities are typically highly dependent on natural resources to sustain their livelihoods and, therefore, deserve voice and control when decisions about natural resources are being made [68]. Adaptive actions need to address livelihood, food, water and energy demands that are context specific. With this in mind, local knowledge and practice should be considered as the foundation cornerstone for conversations on environmental sustainability and should inform adaptation responses [54,69]. Whilst it is widely agreed that successful adaptation is contextually dependent, few studies empirically explore how people perceive and respond to environmental change in specific cultural contexts [54,70]. As environmental change reshapes social-ecological relationships, more attention needs to be paid to the sustainability of response strategies adopted to adapt to such change. Lessons of positive 
transformations need to be learned and their potential of being replicated and applied explored. At the centre of these more virtuous response strategies is the requirement for effective integration of local community insights into research exploring the effects of change and roots to adaptation.

The DESL framework attempts to facilitate better understandings of how people respond to environmental change to meet their water, energy and food needs. The framework includes temporal and spatial dimensions so that the effects of change over time and space can be identified. The DESL framework can be effective for capturing long-term transitions for how people attain water, energy and food security. One such observation includes the shift from subsistence to income generating livelihoods and the resulting move towards purchasing rather than producing food. This shift in food security acquisition creates a growing reliance on human capital [71]. It is anticipated that declines in production will continue to reduce the space available for farming and declines in production caused by climate change, population increase and loss of soil fertility. Other changes included communities transitioning towards using piped water instead of well water and an increase in people having electrified energy in their homes.

The results also demonstrated that these transitions are not seamless or linear but highly exposed to perturbations, meaning that people experience sharp changes in resource security. Therefore, there is a strong need for responsiveness to change with community connectedness playing a vital role in supporting peoples' ability to cope with shocks and stresses. The findings, however, suggested that resource scarcity and increased movement of people erode social cohesion to some extent. Barriers to preparedness also need to be addressed; for instance, relating to the lack of weather prediction information, modern farming skills, rainwater harvesting and irrigation facilities and forest management skills. The results emphasise the need for strategic planning to protect and enhance resource security considering increased populations, climate change and socio-economic development. According the scenarios pathway narratives produced by communities, forest management, shifts to green, clean energy supplies and enhanced farming education should be central to such planning to reduce pressure on ecosystems and enhance crop production.

In the development of the DESL framework attention was also paid to how local voices could be better captured and interrogated into local decision-making processes. Participatory research methods facilitate the integration of a range of knowledge and provide an opportunity to understand the environmental and social context and combine different expertise to assess the potential impacts of shocks and stresses [49]. Multiscale stakeholder engagement has been used in many participatory processes in an attempt to synthesise diverse knowledge in sustainability research [58,59]. However, in the context of future sustainability planning, the framing of the future trajectories is not always rooted within societal needs but focuses on environmental sustainability. There are many obstacles which impede the integration of local knowledge into decision-making processes around how to manage land use and land cover to ensure environmental sustainability. Power dynamics often lead to bias in decision making processes leading to more marginalised groups making compromises when developing a consensus [72]. Women have been historically underrepresented in decision-making processes, especially in traditionally patriarchal societies [73]. There has been a lack of youth engagement in many decision-making processes around environmental management [74] which has resulted in the impacts of environmental change on children and the youth being often underrepresented. Education and literacy inequalities can also skew the balance of power in participatory processes [75]. Consequently, there is a need for new mechanisms which overcome such challenges and strengthen the agency of local voices in participatory processes exploring the impacts of environmental change alongside routes to adaptation.

By applying the DESL model to the stepwise scenarios process and including an in-depth scoping stage into the study, we were able to reconcile some of the barriers to local knowledge integration. This was done in part by strengthening the agency of communities in both problem framing and pathway theme generation in the early parts of the study. The focus groups also enabled us to learn about social dynamics at household and village levels so that we could carefully plan questioning styles and 
activities in the community-based workshops, ensuring all participants had a role and could be heard. For instance, each participant did their own evaluations of water, energy and food security and were able to individually rank perceived drivers of change, thereby equalising power dynamics in consensus building activities. Inviting a range of age groups and genders also allowed us to assess emerging vulnerabilities and opportunities, as well as social and generational differences between these.

We found the DESL framework as able to facilitate better understanding of how people are responding to environmental change and how this shapes social-ecological relationships over time. However, there are practical considerations that warrant attention; the application of the framework in the stepwise scenarios process suggested requires long periods of fieldwork to develop contextual insights and understand the social ecological system that is inherently complex. In Zanzibar, we found that the separate institutions did not traditionally communicate to form policies across sectors; therefore, some thought also needs to be given to facilitate such processes in the workshop setting. Using a nexus approach also requires knowledge and skills that span different fields (in this case, water, energy and food). Taking such a systematic approach can mean that there is a lack of interrogation of specific issues relating to each of these factors. In addition, the DESL framework application to the scenarios process assumes that communities are static and do not move. For instance, long-term insights of change were required, and there was an assumption that people were rooted to their environment and invested in planning for its future sustainability. However, this might be less likely considering the increased movement of people away from their traditional livelihoods and increased mobility. This application also failed to capture the influence of migrant or transient groups (i.e., seasonal workers) on land use and land cover despite their dependence on natural resources to meet basic needs. Finally, though youth were involved in the scenarios planning procedure, changing aspirations across generations could perhaps be better understood with youth-centred specific research. We have to recognize differentiated pathways to adaptation that are dynamic and tailored to different sectors of the population and that traditional population livelihoods are changing often with multiple pathways in the same geography [71].

\section{Conclusions}

Nexus thinking is needed to understand multiple types of change and their impacts on sustainable livelihoods on small islands, specifically due to the unique conditions they face (being geographically isolated, highly dependent on ecosystem services and facing rapid environmental change due to the multiple drivers operating across a small area). This review adds to the growing body of literature showing that nexus approaches are required to explore environmental sustainability when facing multiple drivers of change. Where many water, energy and food nexus approaches fail to integrate community perspectives into narratives around sustainability, we introduce an integrative conceptual framework which links social-ecological and environmental sustainability thinking to explore livelihood outcomes under changing conditions on small islands. This framework emphasizes the importance of exploring adaptation to rapid environmental change and how these responses reshape social-ecological interactions and ecosystem function and environmental livelihood security. As these interactions are an evolving process, it is important to consider these relationships over appropriate temporal and spatial scales in an iterative approach. This framework can be used to integrate community perspectives into nexus approaches for tackling sustainability challenges. It has the capacity to increase the agency of local communities within decision-making processes and centralise poverty alleviation thinking into sustainable land use planning. We suggest that the framework be used to support local communities to shape problem framing around environmental change and its impacts on livelihoods within future scenarios development using the kesho scenarios approach. The framework was applied to Unguja and Pemba islands in the Zanzibar Archipelago, and the empirical findings are currently being developed. Although the framework was created with specific considerations for sustainability challenges for small islands in the Western Indian Ocean, it could be used in different contexts that experience constraints 
in terms of resources and which are highly threatened by global and local changes that are likely to become more challenging.

Author Contributions: Conceptualization, R.J.S.N.; methodology, R.J.S.N. and C.C.; formal analysis, R.J.S.N.; investigation, R.J.S.N.; writing—original draft preparation, R.J.S.N.; writing—review and editing, R.J.S.N., C.C., C.C.-M., J.P.R.T., R.K., C.E. and R.M.; visualization, R.J.S.N.; supervision, C.E. and R.M.; funding acquisition, R.J.S.N. All authors have read and agreed to the published version of the manuscript.

Funding: This research was funded by the UK Economic and Social Research Council (ESRC) White Rose Doctoral Training Program (WRDTP).

Acknowledgments: Thank you to Natasha Newman who developed the artwork for the conceptual and schematic diagrams. Further thanks to the communities who R.N. worked with across Unguja and Pemba, whose insights helped to shape the theory behind the integrative conceptual framework, as well as the Department of Forestry and Renewable and Non-Renewable Resources in Zanzibar for their continued facilitation and support of R.N.'s wider $\mathrm{PhD}$ project. C.C.-M. and R.K. were supported by the "Adaptation and Resilience to Climate Change (ARCC)" project through the Sustainability and Resilience-Tackling Climate and Environmental Changes Programme funded by the Swedish Research Council (Vetenskapsrådet), SiDA and Formas.

Conflicts of Interest: The authors declare no conflict of interest.

\section{References}

1. International Panel on Climate Change. Climate Change 2014: Impacts, Adaptation, and Vulnerability. Part B: Regional Aspects. In Contribution of Working Group II to the Fifth Assessment Report of the Intergovernmental Panel on Climate Change; Cambridge University Press: Cambridge, UK; New York, NY, USA, 2014; p. 688.

2. International Panel of Biodiversity and Ecosystem Services. Summary for Policymakers of the Regional Assessment Report on Biodiversity and Ecosystem Services for Africa of the Intergovernmental Science-Policy Platform on Biodiversity and Ecosystem Services; Archer, E., Dziba, L.E., Mulongoy, K.J., Walters, M., Biggs, R., Cormier-Salem, M.C., DeClerck, F., Eds.; IPBES Secretariat: Bonn, Germany, 2018; p. 49.

3. McMillen, H.L.; Ticktin, T.; Friedlander, A.; Jupiter, S.D.; Thaman, R.; Campbell, J.; Veitayaki, J.; Giambelluca, T.; Nihmei, S.; Rupeni, E.; et al. Small islands, valuable insights: Systems of customary resource use and resilience to climate change in the Pacific. Ecol. Soc. 2014, 19, 44. [CrossRef]

4. Morelli, J. Environmental Sustainability: A Definition for Environmental Professionals. J. Environ. Sustain. 2011, 1, 1-10. [CrossRef]

5. Marchant, R.; Rucina, S. Synthesizing East African land-cover change over the past 6000 years. Past Glob. Chang. Mag. 2018, 24, 39. [CrossRef]

6. Berkhout, F.; Leach, M.; Scoones, I. Negotiating Environmental Change: New Perspectives from Social Science; Edward Elgar: Northampton, MA, USA, 2003.

7. Kates, R.W.; Clark, W.C.; Corell, R.; Hall, J.M.; Jaeger, C.C.; Lowe, I.; McCarthy, J.J.; Schellnhuber, H.J.; Bolin, B.; Dickson, N.M.; et al. ENVIRONMENT AND DEVELOPMENT: Sustainability Science. Science 2001, 292, 641-642. [CrossRef] [PubMed]

8. Neumann, B.; Vafeidis, A.T.; Zimmermann, J.; Nicholls, R.J. Future Coastal Population Growth and Exposure to Sea-Level Rise and Coastal Flooding_A Global Assessment. PLoS ONE 2015, 10, e0118571. [CrossRef] [PubMed]

9. Adger, W.N. Social Capital, Collective Action, and Adaptation to Climate Change. Econ. Geogr. 2009, 79, 387-404. [CrossRef]

10. Saunders, F; Mohammed, S.M.; Jiddawi, N.; Nordin, K.; Lundén, B.; Sjöling, S. The changing social relations of a community-based mangrove forest project in Zanzibar. Ocean Coast. Manag. 2010, 53, 150-160. [CrossRef]

11. Hampton, M.P.; Jeyacheya, J. Power, Ownership and Tourism in Small Islands: Evidence from Indonesia. World Dev. 2015, 70, 481-495. [CrossRef]

12. Capitani, C.; Garedew, W.; Mitiku, A.; Berecha, G.; Hailu, B.T.; Heiskanen, J.; Hurskainen, P.; Platts, P.J.; Siljander, M.; Pinard, F.; et al. Views from two mountains: Exploring climate change impacts on traditional farming communities of Eastern Africa highlands through participatory scenarios. Sustain. Sci. 2019, 14, 191-203. [CrossRef] 
13. International Panel on Climate Change. Summary for Policymakers. In Global warming of $1.5^{\circ} \mathrm{C}$. In An IPCC Special Report on the Impacts of Global Warming of $1.5^{\circ} \mathrm{C}$ above Pre-Industrial Levels and Related Global Greenhouse Gas Emission Pathways, in the Context of Strengthening the Global Response to the Threat of Climate Change, Sustainable Development, and Efforts to Eradicate Poverty; World Meteorological Organization: Geneva, Switzerland, 2018.

14. Barbier, E.B. Climate change impacts on rural poverty in low-elevation coastal zones. Estuarine Coast. Shelf Sci. 2015, 165, A1-A13. [CrossRef]

15. Liu, J.; Hull, V.; Godfray, H.C.J.; Tilman, D.; Gleick, P.; Hoff, H.; Pahl-Wostl, C.; Xu, Z.; Chung, M.G.; Sun, J.; et al. Nexus approaches to global sustainable development. Nat. Sustain. 2018, 1, 466-476. [CrossRef]

16. Suckall, N.; Tompkins, E.; Stringer, L. Identifying trade-offs between adaptation, mitigation and development in community responses to climate and socio-economic stresses: Evidence from Zanzibar, Tanzania. Appl. Geogr. 2014, 46, 111-121. [CrossRef]

17. Khamis, Z.A.; Kalliola, R.; Käyhkö, N. Geographical characterization of the Zanzibar coastal zone and its management perspectives. Ocean Coast. Manag. 2017, 149, 116-134. [CrossRef]

18. Challinor, A.; Wheeler, T.; Garforth, C.; Craufurd, P.; Kassam, A. Assessing the vulnerability of food crop systems in Africa to climate change. Clim. Chang. 2007, 83, 381-399. [CrossRef]

19. Risbey, J.; Kandlikar, M.; Dowlatabadi, H.; Graetz, D. Scale, context, and decision making in agricultural adaptation to climate variability and change. Mitig. Adapt. Strat. Glob. Chang. 1999, 4, 137-165. [CrossRef]

20. Connell, J. Food security in the island Pacific: Is Micronesia as far away as ever? Reg. Environ. Chang. 2014, 15, 1299-1311. [CrossRef]

21. Ewers, R.M.; Rodrigues, A.S. Estimates of reserve effectiveness are confounded by leakage. Trends Ecol. Evol. 2008, 23, 113-116. [CrossRef]

22. Mustelin, J.; Klein, R.G.; Assaid, B.; Sitari, T.; Khamis, M.; Mzee, A.; Haji, T.; Nalau, J. Understanding current and future vulnerability in coastal settings: Community perceptions and preferences for adaptation in Zanzibar, Tanzania. Popul. Environ. 2010, 31, 371-398. [CrossRef]

23. Alongi, D.M. Present state and future of the world's mangrove forests. Environ. Conserv. 2002, 29, 331-349. [CrossRef]

24. Cinner, J.; McClanahan, T.; Graham, N.; Daw, T.; Maina, J.; Stead, S.; Wamukota, A.; Brown, K. Bodin, Örjan Vulnerability of coastal communities to key impacts of climate change on coral reef fisheries. Glob. Environ. Chang. 2012, 22, 12-20. [CrossRef]

25. Shiferaw, B.; Tesfaye, K.; Kassie, M.; Abate, T.; Prasanna, B.; Menkir, A. Managing vulnerability to drought and enhancing livelihood resilience in sub-Saharan Africa: Technological, institutional and policy options. Weather. Clim. Extrem. 2014, 3, 67-79. [CrossRef]

26. Russell, J.C.; Meyer, J.-Y.; Holmes, N.D.; Pagad, S. Invasive alien species on islands: Impacts, distribution, interactions and management. Environ. Conserv. 2017, 44, 359-370. [CrossRef]

27. Peña-Arancibia, J.L.; Bruijnzeel, L.A.; Mulligan, M.; Van Dijk, A.I. Forests as 'sponges' and 'pumps': Assessing the impact of deforestation on dry-season flows across the tropics. J. Hydrol. 2019, 574, 946-963. [CrossRef]

28. Lange, G.-M. Tourism in Zanzibar: Incentives for sustainable management of the coastal environment. Ecosyst. Serv. 2015, 11, 5-11. [CrossRef]

29. Crowther, A.; Faulkner, P.; Prendergast, M.E.; Morales, E.M.Q.; Horton, M.; Wilmsen, E.; Kotarba-Morley, A.M.; Christie, A.; Petek, N.; Tibesasa, R.; et al. Coastal Subsistence, Maritime Trade, and the Colonization of Small Offshore Islands in Eastern African Prehistory. J. Isl. Coast. Archaeol. 2016, 11, 211-237. [CrossRef]

30. Petzold, J.; Ratter, B.M. Climate change adaptation under a social capital approach-An analytical framework for small islands. Ocean Coast. Manag. 2015, 112, 36-43. [CrossRef]

31. Sharpley, R.; Ussi, M. Tourism and Governance in Small Island Developing States (SIDS): The Case of Zanzibar. Int. J. Tour. Res. 2014, 16, 87-96. [CrossRef]

32. Leach, M.; Fairhead, J. Challenging Neo-Malthusian Deforestation Analyses in West Africa's Dynamic Forest Landscapes. Popul. Dev. Rev. 2000, 26, 17-43. [CrossRef]

33. Biggs, E.M.; Bruce, E.; Boruff, B.; Duncan, J.M.; Horsley, J.; Pauli, N.; McNeill, K.; Neef, A.; Van Ogtrop, F.; Curnow, J.; et al. Sustainable development and the water-energy-food nexus: A perspective on livelihoods. Environ. Sci. Policy 2015, 54, 389-397. [CrossRef]

34. Scoones, I. Sustainable Rural Livelihoods: A Framework for Analysis; IDS Working Paper No. 72; Institute of Development Studies: Brighton, UK, 1998. 
35. Chambers, R.; Conway, G.R. Sustainable Rural Livelihoods: Practical Concepts for the 21st Century; IDS Discussion Paper No. 296; Institute of Development Studies: Brighton, UK, 1992.

36. Scoones, I. Livelihoods perspectives and rural development. J. Peasant. Stud. 2009, 36, 171-196. [CrossRef]

37. Waroux, Y.L.P.D. Livelihoods through the Lens of Telecoupling. Telecoupling 2019, 233-249. [CrossRef]

38. Leach, M.; Scoones, I.; Stirling, A. Dynamic Sustainabilities "Technology, Environment, Social Justice"; Taylor and Francis: Hoboken, NJ, USA, 2010.

39. Carter, N.H.; Viña, A.; Hull, V.; McConnell, W.J.; Axinn, W.; Ghimire, D.; Liu, J. Coupled human and natural systems approach to wildlife research and conservation. Ecol. Soc. 2014, 19. [CrossRef]

40. Chambers, D.A.; Glasgow, R.E.; Stange, K.C. The dynamic sustainability framework: Addressing the paradox of sustainment amid ongoing change. Implement. Sci. 2013, 8, 117. [CrossRef] [PubMed]

41. Bazilian, M.; Rogner, H.; Howells, M.; Hermann, S.; Arent, D.; Gielen, D.; Steduto, P.; Mueller, A.; Komor, P.; Tol, R.S.; et al. Considering the energy, water and food nexus: Towards an integrated modelling approach. Energy Policy 2011, 39, 7896-7906. [CrossRef]

42. Leck, H.; Conway, D.; Bradshaw, M.; Rees, J. Tracing the Water-Energy-Food Nexus: Description, Theory and Practice. Geogr. Compass 2015, 9, 445-460. [CrossRef]

43. Fürst, C.; Luque, S.; Geneletti, D. Nexus thinking-How ecosystem services can contribute to enhancing the cross-scale and cross-sectoral coherence between land use, spatial planning and policy-making. Int. J. Biodivers. Sci. Ecosyst. Serv. Manag. 2017, 13, 412-421. [CrossRef]

44. Folke, C.; Biggs, R.; Reyers, B.; Rockström, J.; Norström, A.V. Social-ecological resilience and biosphere-based sustainability science. Ecol. Soc. 2016, 21. [CrossRef]

45. Capitani, C.; Mukama, K.; Mbilinyi, B.; Malugu, I.; Munishi, P.; Burgess, N.; Platts, P.; Sallu, S.; Marchant, R. From local scenarios to national maps: A participatory framework for envisioning the future of Tanzania. Ecol. Soc. 2016, 21. [CrossRef]

46. Engler, J.-O.; Abson, D.J.; Von Wehrden, H. Navigating cognition biases in the search of sustainability. Ambio 2018, 48, 605-618. [CrossRef]

47. Sherman, M.; Berrang-Ford, L.; Lwasa, S.; Ford, J.; Namanya, D.B.; Llanos-Cuentas, A.; Maillet, M.; Harper, S. IHACC Research Team Drawing the line between adaptation and development: A systematic literature review of planned adaptation in developing countries. Wiley Interdiscip. Rev. Clim. Chang. 2016, 7, 707-726. [CrossRef]

48. Coleman, S.; Hurley, S.; Koliba, C.; Zia, A. Crowdsourced Delphis: Designing solutions to complex environmental problems with broad stakeholder participation. Glob. Environ. Chang. 2017, 45, 111-123. [CrossRef]

49. Kebede, A.S.; Nicholls, R.J.; Allan, A.; Arto, I.; Cazcarro, I.; Fernandes, J.A.; Hill, C.T.; Hutton, C.W.; Kay, S.; Lázár, A.N.; et al. Applying the global RCP-SSP-SPA scenario framework at sub-national scale: A multi-scale and participatory scenario approach. Sci. Total. Environ. 2018, 635, 659-672. [CrossRef] [PubMed]

50. Fagerholm, N.; Käyhkö, N.; Ndumbaro, F.; Khamis, M. Community stakeholders' knowledge in landscape assessments-Mapping indicators for landscape services. Ecol. Indic. 2012, 18, 421-433. [CrossRef]

51. Savo, V.; Lepofsky, D.; Benner, J.P.; Kohfeld, K.E.; Bailey, J.; Lertzman, K. Observations of climate change among subsistence-oriented communities around the world. Nat. Clim. Chang. 2016, 6, 462-473. [CrossRef]

52. Cuni-Sanchez, A.; Omeny, P.; Pfeifer, M.; Olaka, L.; Mamo, M.B.; Marchant, R.; Burgess, N.D. Climate change and pastoralists: Perceptions and adaptation in montane Kenya. Clim. Dev. 2018, 11, 513-524. [CrossRef]

53. Goldman, M.J.; Turner, M.D.; Daly, M. A critical political ecology of human dimensions of climate change: Epistemology, ontology, and ethics. Wiley Interdiscip. Rev. Clim. Chang. 2018, 9, e526. [CrossRef]

54. Thorn, J.P.R. Adaptation "from below" to changes in species distribution, habitat and climate in agro-ecosystems in the Terai Plains of Nepal. Ambio 2019, 48, 1482-1497. [CrossRef]

55. Klein, J.A.; Tucker, C.M.; Steger, C.E.; Nolin, A.; Reid, R.; Hopping, K.A.; Yeh, E.T.; Pradhan, M.S.; Taber, A.; Molden, D.; et al. An integrated community and ecosystem-based approach to disaster risk reduction in mountain systems. Environ. Sci. Policy 2019, 94, 143-152. [CrossRef]

56. Biggs, E.M.; Boruff, B.; Bruce, E.; Duncan, J.M.A.; Haworth, B.J.; Duce, S.; Horsley, J.; Curnow, J.; Neef, A.; McNeill, K.; et al. Environmental livelihood security in Southeast Asia and Oceania: A water-energy-food-livelihoods nexus approach for spatially assessing change. White Pap. 2014. [CrossRef]

57. Rietbergen, S.; Hammond, T.; Sayegh, C.; Hesselink, F.; Mooney, K. Island Voices-Island Choices: Developing Strategies for Living with Rapid Ecosystem Change on Small Islands; IUCN: Gland, Switzerland, 2008. 
58. Tompkins, E.L.; Few, R.; Brown, K. Scenario-based stakeholder engagement: Incorporating stakeholders preferences into coastal planning for climate change. J. Environ. Manag. 2008, 88, 1580-1592. [CrossRef]

59. Mercer, J.; Kelman, I.; Alfthan, B.; Kurvits, T. Ecosystem-Based Adaptation to Climate Change in Caribbean Small Island Developing States: Integrating Local and External Knowledge. Sustainability 2012, 4, 1908-1932. [CrossRef]

60. Evans, M.C.; Cvitanovic, C. An introduction to achieving policy impact for early career researchers. Palgrave Commun. 2018, 4, 88. [CrossRef]

61. Sagoff, M. Aggregation and deliberation in valuing environmental public goods. Ecol. Econ. 1998, 24, 213-230. [CrossRef]

62. Smith, A.; Snapp, S.; Dimes, J.; Gwenambira, C.; Chikowo, R. Doubled-up legume rotations improve soil fertility and maintain productivity under variable conditions in maize-based cropping systems in Malawi. Agric. Syst. 2016, 145, 139-149. [CrossRef]

63. Slade, L.; Thani, A.; Hajj, H.; Mbarouk, S. Water Equity in Tourism: Case Study Zanzibar; Mwambao Coastal Community Network: Mkoani, Tanzania, 2012.

64. Pelling, M.; Uitto, J.I. Small island developing states: Natural disaster vulnerability and global change. Environ. Hazards 2001, 3, 49-62. [CrossRef]

65. Barnett, J. Dangerous climate change in the Pacific Islands: Food production and food security. Reg. Environ. Chang. 2011, 11, 229-237. [CrossRef]

66. Kristoferson, L.; O'Keefe, P.; John, S. Energy in Small Island Economies. Ambio 1985, 14, 242-244.

67. Astuti, S.P.; Day, R.; Emery, S.B. A successful fuel transition? Regulatory instruments, markets, and social acceptance in the adoption of modern LPG cooking devices in Indonesia. Energy Res. Soc. Sci. 2019, 58, 101248. [CrossRef]

68. Mercer, J.; Kurvits, T.; Kelman, I.; Mavrogenis, S. Ecosystem-Based Adaptation for Food Security in the AIMS SIDS: Integrating External and Local Knowledge. Sustainability 2014, 6, 5566-5597. [CrossRef]

69. Leach, M.; Scoones, I.; Stirling, A. Pathways to Sustainability: An Overview of the STEPS Centre Approach; STEPS Approach Paper; STEPS Centre (OA): Brighton, UK, 2007.

70. Tschakert, P.; Barnett, J.; Ellis, N.; Lawrence, C.; Tuana, N.; New, M.; Elrick-Barr, C.; Pandit, R.; Pannell, D. Climate change and loss, as if people mattered: Values, places, and experiences. Wiley Interdiscip. Rev. Clim. Chang. 2017, 8, e476. [CrossRef]

71. Thornton, P.K.; Loboguerrero, A.M.; Campbell, B.M.; Kavikumar, K.S.; Mercado, L.; Shackleton, S. Rural Livelihoods, Food Security and Rural Transformation under Climate Change; GCA: Rotterdam, The Netherlands; Washington, DC, USA, 2019.

72. Cleaver, F. Paradoxes of participation: Questioning participatory approaches to development. J. Int. Dev. 1999, 11, 597-612. [CrossRef]

73. Twyman, J.; Useche, P.; Deere, C.D. Gendered Perceptions of Land Ownership and Agricultural Decision-making in Ecuador: Who Are the Farm Managers? Land Econ. 2015, 91, 479-500. [CrossRef]

74. Biggeri, M.; Arciprete, C.; Karkara, R. Children and Youth Participation in Decision-Making and Research Processes. In The Capability Approach, Empowerment and Participation; Clark, D., Biggeri, M., Frediani, A., Eds.; Rethinking International Development Series; Palgrave Macmillan: London, UK, 2019.

75. Schwilch, G.; Bachmann, F.; Valente, S.; Coelho, C.; Moreira, J.; Laouina, A.; Chaker, M.; Aderghal, M.; Santos, P.; Reed, M.S. A structured multi-stakeholder learning process for Sustainable Land Management. J. Environ. Manag. 2012, 107, 52-63. [CrossRef]

(C) 2020 by the authors. Licensee MDPI, Basel, Switzerland. This article is an open access article distributed under the terms and conditions of the Creative Commons Attribution (CC BY) license (http://creativecommons.org/licenses/by/4.0/). 